\title{
NETRALITAS PEGAWAI NEGERI SIPIL DALAM PILKADA SERENTAK $2015^{1}$
}

\author{
Anggriani Alamsyah ${ }^{1}$, Andi Aslinda ${ }^{2}$ dan Sosiawaty ${ }^{3}$ \\ ${ }^{1}$ Program Studi Ilmu Politik UIN Alauddin Makassar. \\ Email: nanialamsyah@gmail.com \\ ${ }^{2}$ Politeknik Pertanian Negeri Pangkep \\ ${ }^{3}$ Program Studi Ilmu Politik Universitas Muhammadiyah Maluku Utara. \\ Email: sosiawatymasrul@gmail.com
}

\begin{abstract}
ABSTRAK
Aparat pemerintah merupakan pelayan public yang harus netral dalam setiap pelaksanaan tugasnya. Negara kita dalam waktu dekat akan menyelenggarakan pilkada serentak 2015, pilkada tentu saja melalui beragam prosedur yang membutuhkan kerja keras dan dukungan semua pihak. Meskipun membutuhkan dukungan banyak pihak, termasuk aparatur pemerintah, namun seorang aparatur pemerintah hendaknya dapat menghindarkan dirinya dari keberpihakan pada salah satu calon. Sebuah Surat Edaran Menteri PANRB nomor B/2355/M.PANRB/07/2015 diterbitkan untuk mempertegas UU No. 5/2014 tentang ASN/PNS. Berdasarkan surat edaran tersebut PNS yang menjadi anggota dan/atau pengurus partai politik, akan dijatuhi hukuman berupa diberhentikan dengan tidak hormat. Selain itu, dalam PP No. 53/2010 tentang Disiplin PNS, juga menegaskan bahwa PNS dilarang memberikan dukungan kepada calon Kepala Daerah/ Wakil Kepala Daerah. Penerbitan surat edaran tersebut ditujukan agar profesionalitas dan pelayanan public oleh para PNS tetap dapat dipertahankan, serta terbebas dari hal-hal yang berbau politik. Tulisan ini bertujuan menggambarkan latar belakang netralitas PNS dari sudut pandang teori-teori birokrasi serta sanksi yang diberikan bila terjadi pelanggaran. Netralitas merupakan hal yang mutlak bagi seorang PNS, namun mereka adalah manusia biasa yang punya motivasi-motivasi tertentu di dalam pelaksanaan tugasnya. Budaya tawar-menawar jabatan, yang di tentukan berdasarkan kedekatan dan sukatidak suka, memungkinkan semakin jauhnya PNS dari sikap netral. Pemerintah yang dalam hal ini Kementerian Pendayagunaan Aparatur Negara dan Reformasi Birokrasi (KemenPAN RB) megeluarkan Surat Edaran Nomor B/2335/M.PANRB/07/2015 tertanggal 22 Juli 2015, yang mengimbau agar seluruh PNS netral dalam Pilkada. Sanksi yang diberikan adalah pencopotan jabatan bila kemudian terbukti memanfaatkan fasilitas-fasilitas Negara dan dengan sengaja mengakibatkan kerugian bagi orang banyak.
\end{abstract}

Kata kunci : Aparat Pemerintah, Netralitas PNS, Sanksi

\begin{abstract}
Government officials should have neutrality in their performance of duties. Our country in the near future will hold local elections of 2015, the elections of course through a variety of procedures that require hard work and support of all parties. Although it requires the support of many parties, including government officials, but the government apparatus should be refrained from siding on one of the candidates. Minister PANRB issued regulation number B / 2355 / M.PANRB / 07/2015 to reinforce the Law 5/2014 on the ASN / PNS. Based on this regulation, civil servants

\footnotetext{
${ }^{1}$ Makalah dipresentasikan dalam Seminar Nasional Menyongsong Pilkada Serentak yang diselenggarakan oleh Program Studi (S1 \& S2) Ilmu Politik Universitas Hasanuddin bekerjasama dengan Dewan Kehormatan Penyelenggara Pemilu (DKPP) RI, Komisi Pemilihan Umum (KPU) RI, Badan Pengawas Pemilihan Umum (Bawaslu) RI dan Asosiasi Ilmu Politik Indonesia (AIPI) Pengurus Cabang Kota Makassar pada 10 November 2015.
} 
who are members and / or political party official, would be sentenced to be dishonourably discharged. In addition, in PP 53/2010 about PNS Discipline, also confirmed that civil servants are prohibited from providing support to candidates for Regional Head / Deputy Head of Region. The issuance of the regulation intended for professional and public services by civil servants can still be maintained, and free from political disputes. This paper aims to describe the background of the neutrality of civil servants from the viewpoint of theories of bureaucracy and sanctions provided in case of infringement. Neutrality is an absolute issue for a civil servant, but they are ordinary people who have certain motivations in the execution of their duties. Cultural of position bargaining, which is determined based on proximity and likes-dislikes, allowing more and more away from the neutrality of civil servants. The Government, in this case the Ministry of Administrative Reform and Bureaucratic Reform (Kemenpan RB) issued regulation No. B / 2335 / M.PANRB / 07/2015 dated July 22, 2015, which appealed to all civil servants neutrality in the elections. Sanctions provided is loss of position if later proven utilizing the facilities of thesState and intentionally causes damages to people.

Keywords : Government officials, Neutrality of Civil Servant, Sanction

\section{PENDAHULUAN}

Pilkada serentak merupakan perhelatan yang baru bagi bangsa Indonesia, dimana pemilihan kepala daerah serentak dilakukan di 262 daerah. Husni Kamil menguraikan saat konfrensi pers di kantornya Jalan Imam Bonjol Jakarta bahwa sampai hari ini (Selasa 11 Agustus 2015) jumlah pasangan calon yang mendaftar ada 852 pasangan calon, terdiri dari 21 pasangan calon untuk pemilihan gubernur dan wakil gubernur, 714 untuk pemilihan bupati/wakil bupati, serta 117 pasangan calon untuk pemilihan walikota dan wakil walikota, dengan rincian 9 Provinsi, 219 kabupaten, dan 33 kota.

Perhelatan ini tentu membutuhkan beragam dukungan dan bantuan dari semua pihak. Seluruh lapisan anak bangsa hendaknya memberikan sumbangsihnya bagi berhasilnya pilkada serentak ini. Namun, dukungan dan bantuan tersebut hendaknya dalam porsinya masing-masing dan tidak keluar dari norma dan aturan-aturan yang berlaku. Dukungan ini juga berasal dari para Aparatur Sipi Negara (ASN), namun dukungan ini tidak boleh keluar dari prinsip netralitas yang harus dipegang oleh stiap individu ASN. Prinsip netralitas ini perlu dijaga agar profesionalitas dan pelayanan public yang merupakan tugas utama mereka, tetap dapat dilaksanakan dengan maksimal.

Netralitas birokrat ini diatur dalam Peraturan Pemerintah (PP) Nomor 53 Tahun 2010 tentang disiplin PNS, bahwa kepala daerah bertanggung jawab menegakkan sanksi kepada PNS yang terlibat pelanggaran dalam pilkada, baik dalam hal netralitas maupun pemanfaatan fasilitas Negara. Karena kepala daerah adalah PPK (pejabat Pembina kepegawaian). Institusi birokrasi dan individu birokrat harus dijaga ketidakberpihakannya kepada salah satu peserta pilkada, semua kandidat harus diperlakukan sama, tanpa perbedaan baik dalam hal keterlibatan langsung, maupun tidak langsung. Ketidakberpihakan ini juga berlaku untuk pemberian fasilitas Negara 
untuk mereka gunakan, terutama jika kandidatnya adalah petahana. UU No. 5 TAhun 2014 tentang ASN juga mengatur hal ini, bahwa dalam upaya menjaga netralitas ASN dari pengaruh partai politik dan untuk menjamin keutuhan, kekompakan, dan persatuan ASN, serta dapat memusatkan segala perhatian, pikiran, dan tenaga pada tugas yang dibebankan, ASN dilarang menjadi anggota dan/atau pengurus partai politik.

Netralitas merupakan salah satu azas penyelenggaraan kebijakan dan Manajemen ASN dalam UU No 5 Tahun 2014 tentang Aparatur Sipil Negara. Yang dimaksud dengan "asas netralitas" adalah bahwa setiap Pegawai ASN tidak berpihak dari segala bentuk pengaruh manapun dan tidak memihak kepada kepentingan siapapun.

Namun aturan tinggallah aturan, bawaslu masih menemukan adanya dugaan mobilisasi PNS dan Satuan Kerja Perangkat Daerah oleh calon petahana selama masa pendaftaran pilkada serentak 2015, bahkan ada beberapa pejabat tinggi daerah yang sempat hadir, sebagaimana dikatakan oleh salah satu komisioner Bawaslu, Nasrullah. Modus lain, tambahnya, dengan memasang foto petahana atau iklan di media untuk memberikan ucapan.

Menurut Weber, birokrat tidak mempunyai kepentingan pribadi apapun dalam menjalankan jabatannya. Seluruh tindakan birokrat adalah rationally purposeful actions yang dikendalikan oleh rational understanding. Dengan rationally purposeful actions dimaksudkan bahwa individu mencoba mencapai tujuan-tujuan tertentu dengan memilih sarana-sarana yang tepat (Henderson and Parsons, 1947:91) dalam Kadir (2011). Weber memang sangat menekankan perlunya pemisahan antara hal-hal yang sifatnya pribadi dan organisasi. Membawabawa kepentingan pribadi ke dalam urusan organisasi merupakan hal yang "haram" hukumnya dalam tipe ideal birokrasi ala Weber.

Dari apa yang tergambar dalam tipe ideal birokrasi Weber menunjukkan bahwa wajar kiranya jika para birokrat tidak terlibat baik langsung maupun tidak langsung dalam proses pilkada maupun pemilu, menyangkut dukungan aktif terhadap salah satu calon. Tulisan ini bertujuan menggambarkan latar belakang netralitas PNS dari sudut pandang teori-teori birokrasi dikaitkan dengan pilkada serentak 2015, serta sanksi yang diberikan bila terjadi pelanggaran. 


\section{TINJAUAN TEORITIS}

\section{Konsep Birokrasi.}

Istilah birokrat, birokratik dan birokrasi ditujukan untuk menunjukkan hal yang kejam dan digunakan sebagai kata yang menghina ketika seseorang dalam keadaan marah. Tak ada seorangpun yang menganggap dirinya birokrat atau mempunyai metode manajemen yang birokratik. Kata-kata ini selalu diaplikasikan dengan konotasi yang tanpa rasa hormat. Kata-kata ini selalu menunjukkan sebuah kritik atas orang, institusi, atau prosedur. Tak seorangpun meragukan bahwa birokrasi sama sekali buruk dan harus lenyap dari muka bumi. Implikasi yang kejam terhadap istilah ini bukan hanya terbatas di Amerika dan Negara-negara demokratis lainnya. Ini adalah fenomena universal. Setiap orang tampaknya setuju bahwa birokrasi itu jahat. Tapi benar bahwa tak seorangpun mencoba untuk menunjukkan apa makna yang sebenarnya dari birokrasi. Kata ini sifatnya longgar. Kebanyakan orang akan malu jika seseorang menanyakan apa definisi dan penjelasan yang tepat dari kata tersebut. Bagaimana mereka mengutuk birokrasi dan birokrat, jika mereka tak tahu arti sebenarnya? (Mises, 2007).

Makna negative dari kata ini memang telah mewabah di seluruh dunia termasuk Indonesia, sering kita dengar kalimat "birokratis sekali" untuk menunjukkan proses yang berbelit-belit untuk suatu urusan. Para pejabat yang tidak menunjukkan keberpihakan pada rakyat banyak biasanya akan di cap sebagai birokrat. Nyaris tidak ada makna positif jika kita menyebutkan kata-kata ini, walaupun belum tentu semua orang paham apa yang dimaksud birokrat, birokratis, dan birokrasi.

Birokrasi pada awalnya adalah istilah untuk menunjukkan metode pemerintah. Birokrasi adalah instrumen pelaksanaan dari rencana-rencana besar di dalam pemerintahan. Birokrasi adalah perangkat permanen dari pemerintah. Istilah birokrasi pada awalnya netral, tidak mengandung konotasi nilai. Dalam perkembangannya istilah birokrasi telah dimuati dengan 
berbagai sifat negatif. Birokrasi dipandang sebagai perangkat pemerintah yang melaksanakan pelayanan yang eksklusif dan sewenang-wenang tanpa spirit public (Kadir, 2011).

Bila kita berbicara organisasi berarti kita berbicara pemerintah, pemerintah dalam hal ini berada dalam sebuah organisasi public. Organisasi public merupakan suatu organisasi yang melayani kepentingan-kepentingan public tanpa membedakan antara satu dengan lainnya, namun dalam perkembangannya, hal ini tidak selalu sejalan dalam kenyataan, keberpihakankeberpihakan para birokratnya, menambah konotasi negative dari kata-kata ini.

Kamus Akademi Perancis memasukkan kata bureaucratie tersebut dalam suplemennya pada tahun 1798 dan mengartikannya sebagai "kekuasaan, pengaruh dari para kepala dan staf biro pemerintahan" (Albrow, 2005:3). Kamus Bahasa Jerman edisi 1813 mendefinisikan birokrasi sebagai "wewenang atau kekuasaan yang berbagai departemen pemerintah dan cabangcabangnya memperebutkan untuk diri mereka sendiri atas sesama warga negara" (Albrow, 2005:3). Kamus Teknik Bahasa Italia tahun 1828 mengartikannya sebagai berikut: "suatu kata baru, yang artinya kekuasaan pejabat di dalam administrasi pemerintahan” (Albrow, 2005:3) dalam Kadir (2011).

Masih dalam Kadir (2011), penjelasan di atas menunjukkan bahwa asal-usul kata birokrasi mencakup gagasan ganda, yaitu sebagai suatu bentuk pemerintahan di mana kekuasaan berada di tangan para pejabat, dan sebagai karakter dari para pejabat tersebut. Hal ini berarti penggunaan istilah birokrasi sejak awal telah diwarnai perdebatan struktural dan keperilakuan. Di satu sisi birokrasi dianggap sebagai suatu bentuk pemerintahan baru, sebagai tandingan dari monarki, aristokrasi dan demokrasi. Di sisi lain birokrasi dihubungkan dengan gaya para pejabat tersebut di dalam menjalankan kekuasaan dan dominasinya.

\section{Birokrasi Dalam Sebuah Demokrasi}

Sangat sering kita dengar bahwa manajemen birokratik tidak sesuai dengan pemerintah dan lembaga demokratik. Ini adalah kesalahan. Demokrasi menunjukkan supremasi hukum. Jika terjadi sebaliknya, pejabat tidaklah bertanggung jawab dan tidak adil dan hakim tidak konstan dan diputuskan tiba-tiba. Dua pilar pemerintah demokratis adalah pentingnya hukum dan anggaran. Pemerintah demokratik adalah system pemerintahan dimana para pemegang kekuasaan dalam posisi untuk menentukan, secara langsung atau tidak langsung dipilih dalam sebuah pemilihan, menjalankan kekuasaan legislative dan eksekutif dan seleksi eksekutif utama. 
Supremasi hukum berarti tidak ada hakim atau pejabat mempunyai hak untuk mencampuri urusan individu, kecuali hukum yang valid memintanya atau memperkuatnya untuk melakukan hal tersebut (Mises, 2007).

Pemerintah yang demokratis mengindikasikan pentingnya pemberian porsi yang besar pada hukum dan anggaran. Atas dasar hukumlah semua tindakan yang dilakukan atau tidak dilakukan oleh seorang pejabat, dengan demikian barulah dia dianggap sebagai pejabat yang adil dan bertanggung jawab atas amanah yang dilimpahkan kepadanya.

Administrasi, dalam sebuah komunitas demokratik, tidak hanya terikat dengan hukum tapi juga oleh anggaran. Control demokratik adalah control penganggaran. Para wakil rakyat punya kunci kendali keuangan. Tidak sepeserpun yang bisa dibelanjakan tanpa persetujuan parlemen. Penggunaan dana public selain alokasi pengeluaran yang telah disetujui parlemen adalah hal yang illegal. Manajemen birokratis berarti, di bawah demokrasi, manajemen harus sejalan dengan hukum dan anggaran. Personil administrasi dan para hakim bukanlah penentu atas apa yang harus dilakukan bagi kesejahteraan rakyat dan bagaimana dana public harus dibelanjakan. Ini adalah tugas penguasa tertinggi, anak bangsa, dan wakil-wakil mereka. Peradilan, berbagai cabang administrasi, angkatan darat, dan angkatan laut menjalankan apa yang hokum dan anggaran perintahkan. Bukan mereka, tetapi kekuasaan pembuatan keputusan. Kebanyakan tiran, penguasa lalim dan dictator meyakinkan bahwa aturan mereka menguntungkan rakyat, bahwa merekalah pemerintah bagi rakyat. Tidaklah perlu untuk menyelidiki bahwa klaim Messrs, Hitler, Stalin, dan Franco berdasar atau tidak. Pada suatu ukuran, system mereka bukanlah pemerintahan rakyat, tidak juga oleh rakyat. Itu bukanlah demokratik, tetapi authoritarian (Mises, 2007).

Weber (dalam Kadir, 2011) menguraikan fungsi-fungsi birokrasi modern dalam bentukbentuk sebagai berikut:

1. Pengorganisasian Fungsi Pejabat Secara Kontinyu dan Ditetapkan dengan Peraturan.

2. Spesifikasi Bidang Kompetensi.

3. Prinsip Hirarkhi.

4. Peraturan Teknis dan Norma untuk Mengatur Pelaksanaan Jabatan.

5. Pemisahan Milik Pribadi Pejabat dengan Milik Organisasi.

6. Tidak ada Penyisihan Pendapatan dari Posisi Resmi Pejabat. 
7. Tindakan, Keputusan, dan Peraturan Administratif Dirumuskan dan Dicatat dalam Tulisan.

\section{HASIL DAN PEMBAHASAN}

Pegawai Aparatur Sipil Negara yang selanjutnya disebut Pegawai ASN adalah pegawai negeri sipil dan pegawai pemerintah dengan perjanjian kerja yang diangkat oleh pejabat pembina kepegawaian dan diserahi tugas dalam suatu jabatan pemerintahan atau diserahi tugas negara lainnya dan digaji berdasarkan peraturan perundang-undangan. Pegawai Negeri Sipil yang selanjutnya disingkat PNS adalah warga negara Indonesia yang memenuhi syarat tertentu, diangkat sebagai Pegawai ASN secara tetap oleh pejabat pembina kepegawaian untuk menduduki jabatan pemerintahan (UU No. 5 Tahun 2014).

Berdasarkan kalimat yang tertera diatas, menggambarkan bahwa seorang PNS adalah orang yang digaji oleh Negara, jadi pengabdiannya harus diberikan sebesar-besarnya untuk kepentingan Negara, bukan untuk kepentingan dirinya sendiri, maupun kelompoknya. Seorang PNS dalam memberikan pelayanan kepa public, hendaknya menghindari diskriminasi ataupun keberpihakan. Larangan keberpihakan ini juga termasuk ketika mereka dihadapkan pada suatu pilihan untuk mendukung atau tidak mendukung salah satu calon kepala daerah, baik itu petahana atau bukan, apapun tawaran yang datang kepada mereka. Ketidakberpihakan ini biasanya diistilahkan dengan netralitas.

Para PNS yang dalam istilah administrasi biasanya dinamakan birokrat, juga adalah seorang manusia biasa, yang punya motivasi-motivasi pribadi, dan kepentingan-kepentingan tertentu dalam menjalankan tugasnya sebagai abdi Negara dan abdi masyarakat. Mereka juga manusia biasa yang butuh sandang, pangan dan status yang bisa lebih mengangkat derajat mereka di mata manusia lainnya.

Sebagaimana dikatakan Riggs bahwa, birokrat pada model sala diwarnai oleh kesibukan mempertahankan karir, masa jabatan, rencana pensiun, hak berlibur, hak cuti, dan untuk 
memperoleh simbol status. Kecenderungan untuk memperkuat kepentingan pribadi, menurut Riggs, sangat nyata dalam birokrasi model sala (Riggs, 1996:380) dalam Kadir (2011). Kecendrungan untuk memperkuat kepantingan pribadi inilah yang banyak dimanfaatkan oleh para calon pemimpin daerah untuk "melamar" para birokrat agar memberikan dukungan kepada mereka baik secara nyata maupun diam-diam, dengan iming-iming jabatan ataupun "mahar" lainnya. Pada saat "lamaran" ini diterima, maka saat itulah prinsip netralitas seorang PNS dilanggar.

Netralitas Pegawai Negeri Sipil selalu menjadi salah satu isu hangat dalam praktek pemilukada. Sumber daya manusia yang dimiliki birokrasi merupakan rebutan bagi para calon khususnya calon incumbent. Hal inipun berlaku timbal balik karena sudah menjadi rahasia umum bahwa akan ada beberapa oknum PNS yang secara tak langsung ikut menjadi tim sukses. Kalau sang calon menang, maka sang oknum ikut menuju kejayaaan paling tidak 5 tahun ke depan. Jika sang calon kalah, maka riwayatnya juga tamat dalam hitungan bulan. Biasanya PNS tidak terang-terangan menjadi tim sukses calon kepala daerah karena hal itu jelas dilarang. Soal dukung mendukung dalam pemilukada ini tentu ada motifnya. Berdasarkan pengalaman menjadi tim sukses dan calonnya, sudah dapat dipastikan promosi jabatan menunggu di depan mata tetapi kalau salah dukung, tunggu saja pembalasan dari sang pemenang. Mutasi jabatan menjadi hal lumrah (Zudi dkk, 2012).

Merujuk kepada gagasan Weber, literatur klasik pada umumnya memandang birokrat atau aparat pemerintahan sebagai instrumen yang mempunyai nilai netral (netral value). Birokrat bukan aparat politik, dia tidak mempunyai kepentingan tertentu dalam mekanisme birokrasi, dia sekedar pelaksana yang tidak perlu tahu ataupun menanyakan ke arah mana tujuan politik atasannya. Dengan rendah hati para administrator mau menerima peraturan-peraturan yang digariskan oleh organ-organ politik, mereka akan mencoba melaksanakan peraturan tersebut secara rasional, memaksimumkan penerimaan pemerintah dan meminimumkan biaya operasional. Apabila prinsip-prinsip itu tidak dapat diwujudkan maka hal tersebut hanya disebabkan sematamata karena para administrator adalah juga manusia biasa yang memiliki dorongan-dorongan jiwa yang tidak rasional sebagaimana dimiliki oleh setiap orang (Riggs, 1996:305) dalam Kadir (2011). 
Karena birokrat bukanlah aparat politik, maka hendaknya dia menjauhkan diri dari halhal yang bisa membuatnya menjadi tidak netral. Dalam UU No. 5 Tahun 2014 dinyatakan bahwa ASN dalam menjalankan profesinya harus berlandaskan pada beberapa prinsip, yakni : nilai dasar; kode etik dan kode perilaku; komitmen, integritas moral, dan tanggung jawab pada pelayanan publik; kompetensi yang diperlukan sesuai dengan bidang tugas; kualifikasi akademik. Nilai dasar dalam prinsip tersebut mempunyai arti, diantaranya: menjalankan tugas secara profesional dan tidak berpihak; menciptakan lingkungan kerja yang nondiskriminatif; mempertanggungjawabkan tindakan dan kinerjanya kepada public.

Beberapa kasus di daerah, sering kali dijumpai keterlibatan PNS dalam mensukseskan salah satu pasangan calon kepala daerah, karena mendapat promosi jabatan basah, jika calon yang diusungnya duduk sebagai kepala daerah terpilih. Diakui atau tidak, banyak PNS yang memanfaatkan Pilkada untuk mengubah nasib. Selama jumlah jabatan sebanding dengan stok sumber daya manusia dari PNS yang secara normatif melalui syarat menduduki jabatan tersebut, maka pilkada dapat dimanfaatkan untuk mengubah konfigurasi pejabat lima tahun ke depan (Zamzani, 2009) dalam Zudi, dkk (2012).

Jauh sebelum adanya istilah pemilihan umum, Weber sudah "menyadari" bahwa seorang birokrat bisa saja tergoda untuk memberikan atau tidak memberikan pelayanannya kepada pihakpihak tertentu. Karenanya, Weber menyatakan bahwa seorang birokrat adalah seorang yang netral, bukan aparat politik yang dapat begitu saja melibatkan dirinya kepada salah satu partai atau calon pemimpin politik. Pemerintah Indonesia pun, sudah mengantisipasi hal ini dengan menyatakan bahwa Pegawai ASN harus bebas dari pengaruh dan intervensi semua golongan dan partai politik (UU No. 5/2014 Pasal 9 ayat 2). PP No. 53/2010 tentang Disiplin PNS, juga menegaskan bahwa PNS dilarang memberikan dukungan kepada calon Kepala Daerah / Wakil Kepala Daerah.

Pada kenyataannya hal ini masih sering dilanggar, beberapa kasus yang memang sudah jelas terbukti secara sah telah terjadi mobilisasi PNS, namun tidak ada tindanya nyata yang diambil untuk menindakinya. Karenanya, hal tersebut tetap terjadi hampir di semua tempat penyelenggaraan pilkada. Terkait pilkada serentak 2015, Bawaslu sebelumnya menemukan adanya dugaan mobilisasi PNS dan Satuan Perangkat Kerja Daerah (SKPD) oleh calon petahana selama pendaftaran. Juga pelibatan PNS di dalam proses deklarasi maupun ketika pasangan 
calon melakukan pendaftaran di KPU. Bahkan ada beberapa pejabat tinggi yang hadir. Modus lainnya adalah memasang foto petahana di baliho atau iklan di media untuk memberikan ucapan.

Litbang Prov. Sumatra Barat (2008) dalam Zudi dkk (2012) jelas-jelas menyatakan bahwa bahwa Sistim karir PNS yang tidak jelas, pengangkatan dan pemberhentian seorang PNS dari suatu jabatan seringkali lebih didasarkan pada like and dislike atau faktor kedekatan. Hal itu mendorong untuk mencari kiat-kiat dan peluang agar bisa mengambil hati atau mendekatkan diri dengan penguasa (calon penguasa). Disadari atau tidak, kebijakan yang tidak jelas mengenai karir PNS, serta kenyataan yang dialami PNS bahwa mereka yang berkontribusi untuk terpilihnya seseorang dalam jabatan politik (tim sukses) akan mendapat posisi yang baik di lingkungan pemerintahan.

Kenyataan di atas sekali lagi mendukung Downs (1964:2) dalam Kadir (2011) yang mengemukakan suatu teori yang berbasis hipotesis fundamental bahwa para pejabat birokratik, seperti halnya para agensi lainnya di masyarakat, dimotivasi oleh kepentingan pribadinya. Kepentingan untuk memperoleh atau mempertahankan jabatan, kepentingan untuk memperoleh uang yang lebih banyak, serta status social di masyarakat, menjadi motivasi yang memungkinkan terjadinya pelanggaran netralitas seorang birokrat.

Untuk meminimalisir terjadinya keberpihakan birokrat kepada salah satu pihak maka pemerintah mengeluarkan beragam aturan yang melarang keras seorang PNS / ASN untuk bersikap netral. Beberapa hal yang bisa dikemukakan disini adalah seorang PNS akan diberhentikan tidak dengan hormat apabila menjadi anggota dan/atau pengurus partai politik (UU NO 5/2014 Pasal 87). Sesuai dengan UU NO 5/2014 maka Menteri Pedayagunaan Aparatur Negara dan Reformasi Birokrasi (PAN-RB) Yuddy Chrisnandi mengeluarkan Surat Edaran nomor B/2355/M.PANRB/07/2015 tanggal 22 Juli 2015 yang menegaskan agar para Aparatur Sipil Negara (ASN) tetap bersikap netral. Surat tersebut ditujukan kepada para Menteri Kabinet Kerja, Panglima TNI, Kapolri, Jaksa Agung, para Kepala Lembaga Pemerintah Non Kementerian (LPNK), para Sekjen Lembaga Negara, para Pimpinan Kesekretariatan Lembaga Non Struktural, para Gubernur, Bupati, dan Walikota.

Menurut Kepala Biro Hukum, Komunikasi, dan Informasi Publik (Hukip) Herman Suryatman, surat tersebut diterbitkan untuk mewujudkan ASN yang bersih dan bebas dari intervensi politik. "ASN harus tetap menjaga keprofesionalitasannya dan memberikan pelayanan publik. Tidak malah ribet dalam urusan politik," ujarnya di Jakarta, Jumat (24/7). Untuk menjamin efektivitas surat edaran tersebut, para pimpinan $\mathrm{K} / \mathrm{L}$ dan Pemda diminta untuk 
melakukan pengawasan terhadap ASN yang berada di lingkungan instansi masing-masing. "Jika ada yang melakukan pelanggaran, langsung dicatat dalam berita acara," tegasnya. Herman menambahkan, selain menjaga netralitas dalam pilkada, aset pemerintah dilarang dipergunakan untuk kampanye. "Kendaraan dinas, ruang rapat, dan perlengkapan kantor tidak boleh digunakan untuk kegiatan politik," tegas Herman. ASN dilarang membuat keputusan dan atau tindakan yang menguntungkan atau merugikan salah satu pasangan calon selama masa kampanye, dan atau mengadakan kegiatan yang mengarah kepada keberpihakan terhadap pasangan calon yang menjadi peserta pemilu, sebelum, selama, dan sesudah masa kampanye. "Larangan ini meliputi kegiatan pertemuan, ajakan, imbauan, seruan, atau pemberian barang kepada PNS dalam lingkungan unit kerjanya, anggota keluarga, dan masyarakat,” imbuhnya (jpnn.com diunduh 23 Oktober 2015).

Netralitas birokrasi dan individu birokratnya memang akan tetap menjadi hal yang menarik untuk dibahas jika pembenahan ke dalam organisasi public tidak segera dilakukan. Sanksi-sanksi yang tertulis dalam aturan-aturan yang ada, tidaklah cukup untuk membuat para pelanggarnya jera. Pemerintah hendaknya lebih patuh pada aturan-aturan kepangkatan / jabatan yang telah dibuatnya sendiri, bukan hanya berdasarkan like/dislike yang menjadikan seseorang untuk melakukan apa saja untuk memperoleh jabatan yang diinginkannya, termasuk mendukung salah satu calon pemimpin daerah. 


\section{KESIMPULAN DAN SARAN}

Birokrasi pada awalnya adalah istilah untuk menunjukkan metode pemerintah. Birokrasi adalah instrumen pelaksanaan dari rencana-rencana besar di dalam pemerintahan. Birokrasi adalah perangkat permanen dari pemerintah. UU NO. 5/2014 dalam Pasal 12 menyatakan bahwa Pegawai ASN berperan sebagai perencana, pelaksana, dan pengawas penyelenggaraan tugas umum pemerintahan dan pembangunan nasional melalui pelaksanaan kebijakan dan pelayanan publik yang profesional, bebas dari intervensi politik, serta bersih dari praktik korupsi, kolusi, dan nepotisme. Sedangkan pada Pasal 27 KASN merupakan lembaga nonstruktural yang mandiri dan bebas dari intervensi politik untuk menciptakan Pegawai ASN yang profesional dan berkinerja, memberikan pelayanan secara adil dan netral, serta menjadi perekat dan pemersatu bangsa.

Birokrat sebagai sebagai perencana, pelaksana, dan pengawas penyelenggaraan tugas umum pemerintahan dan pembangunan nasional melalui pelaksanaan kebijakan dan pelayanan publik yang profesional hendaknya tetap menjaga dirinya agar tetap netral dan adil. Perhelatan pemilihan kepala daerah memang merupakan "obyek" yang menggoda untuk dijadikan ajang "adu nasib" dalam pencarian jabatan. Namun, hal ini bukan tanpa resiko, karena calon yang kita dukung belum tentu memenangkan pemilihan tersebut. Terlepas dari menang atau tidak, ini bukanlah tindakan yang terpuji, seorang ASN/PNS hendaknya menjauhkan diri dari hal-hal seperti ini. 
Pemerintah telah mengeluarkan berbagai aturan untuk melarang keberpihakan para birokratnya kepada salah satu calon pemimpin daerah, hal ini sebaiknya diikuti dengan perbaikan ke dalam dengan mematuhi aturan kepangkatan/jabatan yang telah ada. Pembinaan akhlak untuk tidak menghalalkan segala cara untuk memperoleh jabatan, hendaknya juga dicontohkan oleh para atasan, agar ia bisa menjadi role model sebagai seorang birokrat yang bersih, netral dan adil, sesuai yang diamanatkan dalam UU NO 5/2014.

\section{DAFTAR PUSTAKA}

Kadir, Abdul. 2011. Disertasi. Karakteristik Birokrasi Max Weber Pada Organisasi Perangkat Daerah Kota Kendari Provinsi Sulawesi Tenggara. Administrasi Publik Universitas Hasanuddin.

Meier. Kenneth J. O' Toole Jr, Laurence. 2006. Bureaucracy in a Democratic State. A Governance Perspective. Baltimore: The Johns Hopkins University Press

Mulyono, Z.R.P.TJ. 2008. Tesis. Kebijakan Netralitas Politik Pegawai Negeri Sipil Dalam Perspektif Perlindungan Hak Asasi Manusia Di Indonesia. Program Magister Ilmu Hukum Program Pasca Sarjana Universitas Diponegoro Semarang.

Udy, Jr, Stanley H. 1959. "Bureaucracy" and "Rationality" in Weber's Organization Theory: An Empirical Study. American Sociological Review, Vol. 24, No. 6 (Dec., 1959), pp. 791-795. jstor. Org.

Von Mises, Ludwig. 2007. Bureaucracy. Indianapolis: Liberty Fund.

Zudi, Mat dkk. 2012. Netralitas Pegawai Negeri Sipil Dalam Pemilihan Kepala Daerah. Diponegoro Law Review, Volume 1, Nomor 4, Tahun 2012. Jurusan Ilmu Hukum, Fakultas Hukum, Universitas Diponegoro

UU NO 5 TAHUN 2014 Tentang Aparatur Sipil Negara (ASN)

PP No. 53/2010 tentang Disiplin PNS

Surat Edaran Menteri PANRB nomor B/2355/M.PANRB/07/2015 tanggal 22 Juli 2015. 
